August 1999 - NREL/SR-550-26846

\title{
New Home Buyer Solar Water Heater Trade-Off Study
}

Symmetrics Marketing Corporation Mesa, Arizona

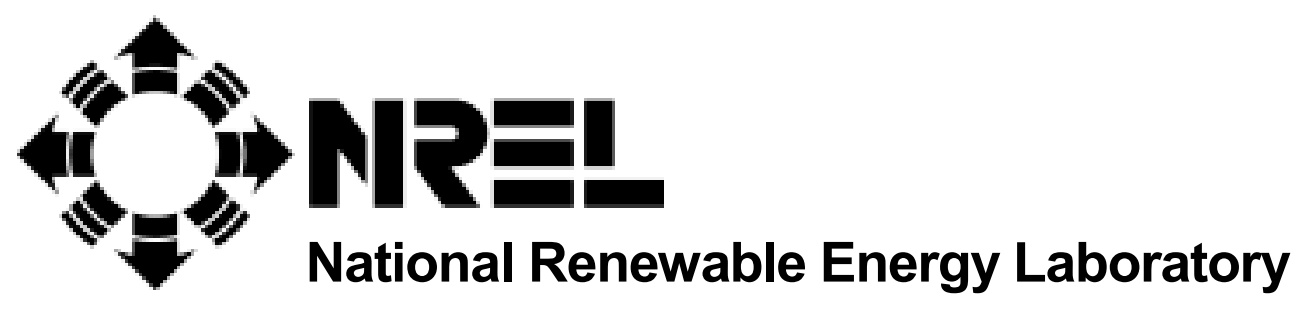

1617 Cole Boulevard

Golden, Colorado 80401-3393

NREL is a U.S. Department of Energy Laboratory

Operated by Midwest Research Institute $\bullet$ Battelle $\bullet$ Bechtel

Contract No. DE-AC36-98-G010337 


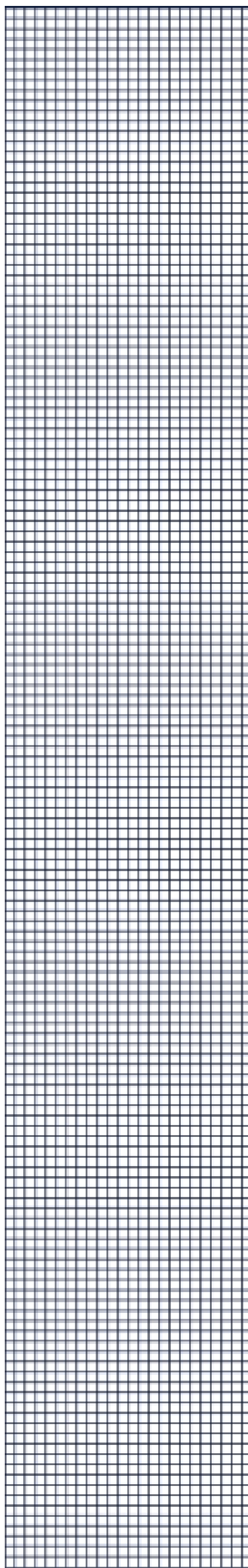

August 1999 - NREL/SR-550-26846

\section{New Home Buyer Solar Water Heater Trade-Off Study}

Symmetrics Marketing Corporation Mesa, Arizona

NREL Technical Monitor: R. Hewett

Prepared under Subcontract No. AAD-8-18615-01

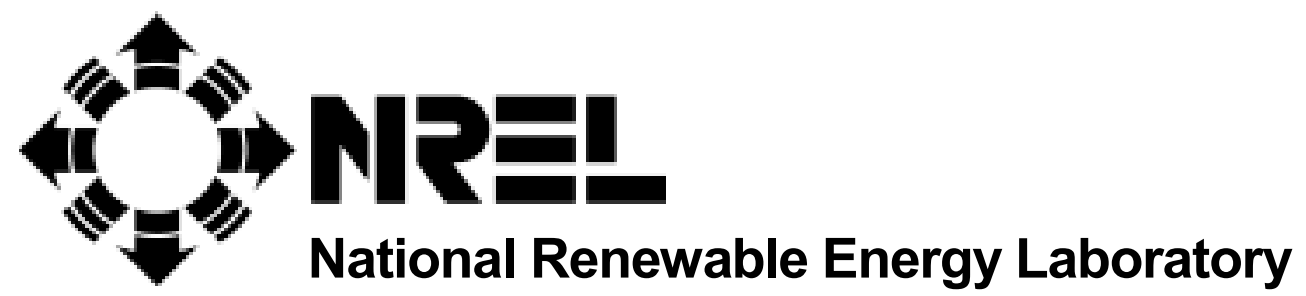

1617 Cole Boulevard

Golden, Colorado 80401-3393

NREL is a U.S. Department of Energy Laboratory

Operated by Midwest Research Institute $\bullet$ Battelle $\bullet$ Bechtel

Contract No. DE-AC36-98-G010337 
This publication was reproduced from the best available copy Submitted by the subcontractor and received no editorial review at NREL

\section{NOTICE}

This report was prepared as an account of work sponsored by an agency of the United States government. Neither the United States government nor any agency thereof, nor any of their employees, makes any warranty, express or implied, or assumes any legal liability or responsibility for the accuracy, completeness, or usefulness of any information, apparatus, product, or process disclosed, or represents that its use would not infringe privately owned rights. Reference herein to any specific commercial product, process, or service by trade name, trademark, manufacturer, or otherwise does not necessarily constitute or imply its endorsement, recommendation, or favoring by the United States government or any agency thereof. The views and opinions of authors expressed herein do not necessarily state or reflect those of the United States government or any agency thereof.

Available to DOE and DOE contractors from:

Office of Scientific and Technical Information (OSTI)

P.O. Box 62

Oak Ridge, TN 37831

Prices available by calling (423) 576-8401

Available to the public from:

National Technical Information Service (NTIS)

U.S. Department of Commerce

5285 Port Royal Road

Springfield, VA 22161

(703) $605-6000$ or (800) 553-6847

or

DOE Information Bridge

http://www.doe.gov/bridge/home.html 


\section{SRP/NREL New Home Buyer Solar Water Heater Trade-off Study}

Summary Report for Public Release

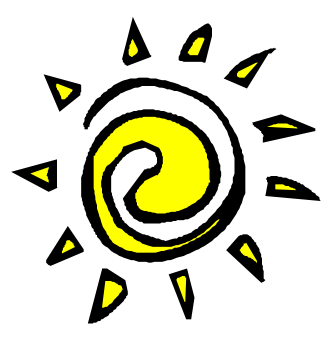

SYMMETRICS MARKETING CORPORATION June 1998 


\section{Background \& Purpose}

- A solar water heater is but one of several features that a buyer might look for in a new home. Budget limitations usually force buyers to make tradeoff decisions among features in order to keep the price of the home within their range. To the extent the desired bundle of features proves affordable, the buyer is more inclined to buy the house.

- This research is intended to calibrate the relative "utility" or importance of the solar water heater vis-a-vis other housing features in new home buyer decision-making. It is also intended to uncover the demographic and psychographic characteristics of new home buyers that are most correlated with the perceived utility of the solar water heater. In addition, the study will examine which features of the solar water heater, itself, are most valued by new home buyers when making home buying decisions. 


\section{Research Objectives}

- The main objective of this study was to conduct quantitative marketing research targeted at new home buyers in order to guide product design and marketing strategies for solar water heaters. The specific research objectives were as follows:

$>$ To determine the relative utility (preference) of solar water heaters as compared to other home upgrade options

$>$ To determine the features and attributes of solar water heaters that would maximize consumer interest and market penetration

$>$ To better understand how to market solar water heaters to particular consumer segments by examining the demographic and/or psychographic correlates of solar water heater purchase interest 


\section{Methodology Overview}

- Face-to-face interviews were conducted with individuals or couples (decision-making units or DMUs) who had purchased a new home within the past 24 months.

$>200$ interviews in Phoenix

- 100 with homes $\$ 100 \mathrm{~K}$ - $\$ 150 \mathrm{~K}$ (referred to in this report as Phoenix Low-End)

- 100 with homes $\$ 150 \mathrm{~K}$ - $\$ 200 \mathrm{~K}$ (referred to in this report as Phoenix Hi-End)

$>100$ interviews in Las Vegas

- All with homes $\$ 100 \mathrm{~K}$ - $\$ 150 \mathrm{~K}$

$>35 \%$ individuals, $65 \%$ couples

- Pretest conducted in Phoenix to test and refine the research methodology

- Interviews conducted between March 5 and March 23, 1998 


\section{Methodology (cont'd)}

- Lists of recent home buyers (past 24 months) were obtained from list brokers in the Phoenix and Las Vegas markets. Recent home buyers were then contacted by telephone and screened for eligibility.

$>$ decision-maker in home purchase past 24 months

$>$ bought home in desired price range

$>$ joint decision-maker invited to participate as well

$>$ security screening (no utility employees or market researchers)

$>$ does not currently own a solar water heater (Of those who participated in the study, 24 of the DMUs (8\%) had had a solar water heater in a previous home.)

$>$ excluded those "extremely unlikely" to purchase solar

- Qualified participants were invited to a focus group facility for a faceto-face interview and were offered a $\$ 50$ incentive to participate. 


\section{Research Design Process}

- The study design for this project was developed and refined by a team of individuals from several organizations. The core team consisted of individuals from Symmetrics Marketing, SRP, NREL and Sandia Labs. This team worked together on all major design issues including:

$>$ deciding on the markets (Phoenix and Las Vegas) and the price points for recent home buyers

$>$ deciding on what the trade-off/conjoint exercises would be

$>$ determining which home upgrade options would be included in the pairwise trade-off

$>$ determining the six major solar water heater features for the product design conjoint exercise (e.g., Price, Performance, etc.)

$>$ determining the attribute levels within each of the major features (e.g., $\$ 1,000, \$ 2,000, \$ 3,000$ )

$>$ reviewing all study materials including product descriptions

- In addition to the core team members, input was also solicited from individuals at the National Association of Home Builders 


\section{Markets and Price Points}

- Markets: The primary market for this solar water heater research was Phoenix given the particular interests of SRP. Co-sponsorship by NREL, however, allowed for the inclusion of a second market. While a number of markets were considered, including Sacramento and Southern California, Las Vegas was chosen by NREL because of its hot, sunny climate (similar to Phoenix) and its explosive growth and home building activity.

- Price Points: The participation of NREL in the study also allowed for the testing of differences in consumer preferences in two different home price ranges. While several price ranges were considered, the team decided to conduct 200 interviews in the $\$ 100,000-\$ 150,000$ range (split between Phoenix and Las Vegas) and 100 interviews in the $\$ 150,000-\$ 200,000$ price range (Phoenix only). This decision was made based on the number of homes built in these price ranges in these markets. While a higher-end luxury home price point was considered, the team decided to conduct this initial research in the larger, mass market. Well over half of the homes built in these markets fall within the selected price ranges. 


\section{Pretesting}

- Once the design was finalized and the study materials were produced, Symmetrics conducted a pretest on March 2 with 1 individual and 4 couples at a focus group facility in Phoenix. Each decision-making unit (DMU) completed both the conjoint "card sort" exercise and the pairwise trade-off of home upgrade options. Following these research tasks, the interviewer de-briefed the participants regarding the ease and understandability of the research tasks.

- Following the pretest, several changes were made to the research tasks to make them clearer and less burdensome for the participants. In addition, changes were made to the conjoint card sort exercise so that the research information would be more actionable from a product design standpoint. These changes are discussed later in this report in the section concerned with the conjoint task. 


\section{Study Tasks}

- Research participants completed several survey tasks during the hour they spent at the research facility. In addition to the conjoint and trade-off tasks, home buyers completed self-administered questionnaires both before and after these exercises.

- Pre-measures -- before exposure to new solar water heaters

$>$ Household demographics

$>$ Purchase intentions (solar water heater and other home upgrades)

$>$ Personal demographics and environmental attitudes

$\checkmark$ Conjoint exercise

$>$ Sorting and ranking of 27 solar water heater profiles

- Pair-wise trade-off

$>21$ pairs of home upgrade options, including solar water heaters and $\$ 2000$ discount

- Post-measures -- after exposure

$>$ Purchase intentions and changes due to exposure 


\section{Research Questions}

- The detailed findings of this study are divided into the major Research Questions that were addressed.

- What is the level of consumer interest in new solar water heater products in relation to other popular home upgrade options offered by builders?

(2) What are the optimal solar water heater designs taking into consideration consumer preference and product feasibility? 


\section{Research Question \#1}

- What is the level of consumer interest in new solar water heater products in relation to other popular home upgrade options offered by builders?

$\checkmark$ Method used

$>$ Purchase intention questions -- solar water heater plus five other upgrade options

- Pre/post-measures

$>$ Pairwise trade-off exercise

- Six upgrade options and an option to receive $\$ 2000$ discount off sales price 


\section{Likely to Buy Solar Water Heaters: Before}

Overall, $60 \%$ of the home buyers said they were extremely/somewhat likely to buy a solar water heater before they were exposed to a description and pictures of newer solar panel technologies. The differences across the markets were not statistically significant.

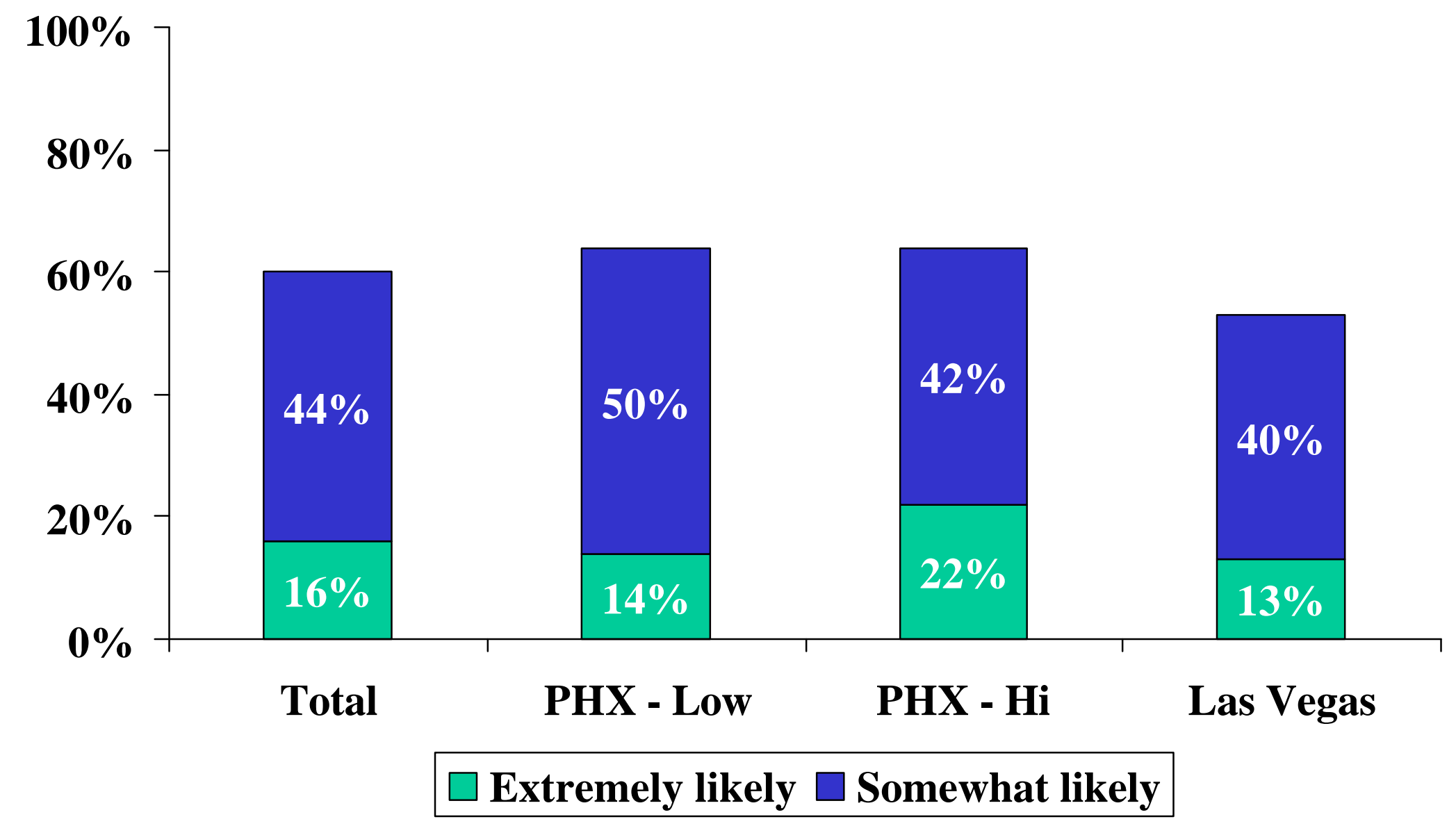




\section{Change in Interest in Solar Water Heaters}

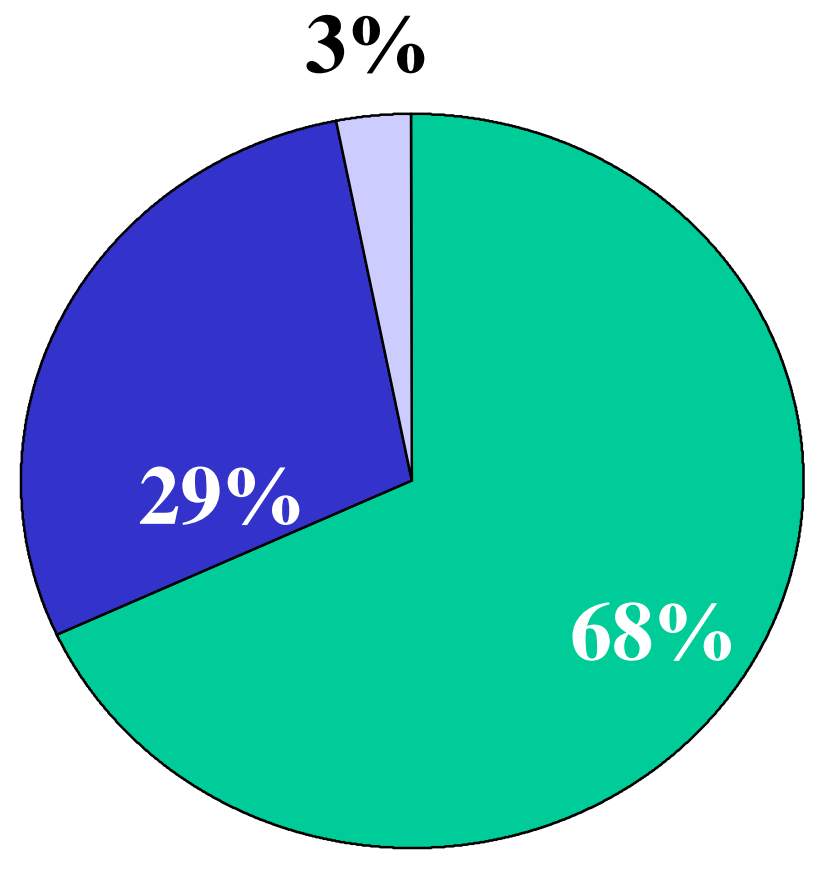

$\square$ More Likely to Buy

$\square$ No Change

$\square$ Less Likely To Buy
- At the end of the interview session, study participants were asked to complete a final questionnaire. One question asked them to rate express their purchase interest in the six tested home upgrade options, including solar water heaters.

- Most respondents were impressed by what they learned about solar water heaters in the study and were more likely to purchase after the study.

- Levels of interest were similar across markets and price points. 


\section{Likely to Buy Solar Water Heaters: After}

The post-measures indicated a substantial increase in interest following the new product description. $74 \%$ of the home buyers claimed they would be extremely/somewhat likely to buy a solar water heater. While this increase was largely the result of focusing on solar during the session, it does suggest that home buyer education could significantly increase product interest.

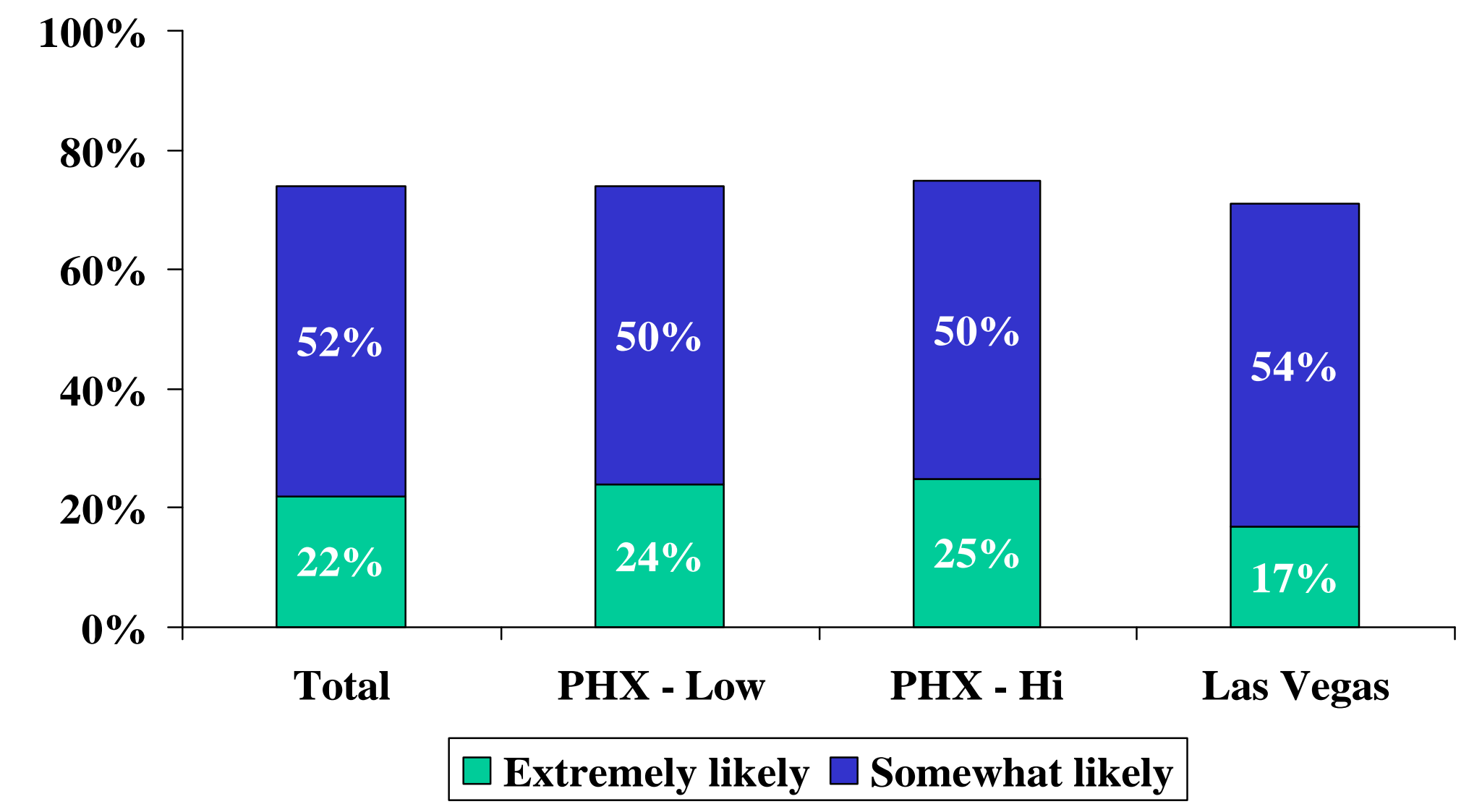




\section{Interest in Solar Water Heaters: Pre/Post}

$\%$ Extremely/Somewhat Likely to Purchase

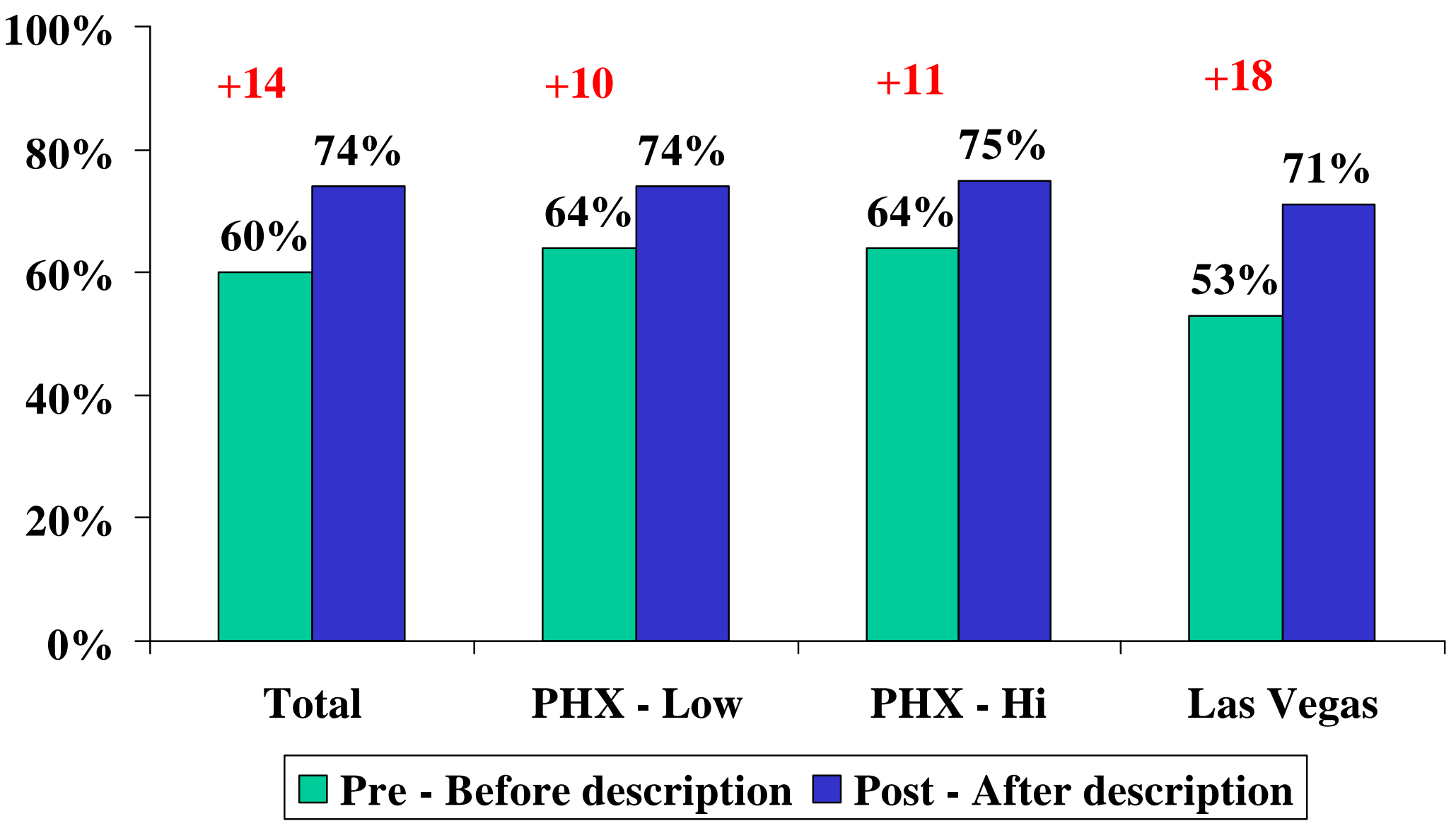




\section{Solar versus Other Upgrades}

- In addition to asking home buyers to rate their likelihood of purchasing a solar water heater, the pre-post surveys also asked their ratings of several other home upgrade options. The most popular upgrade options were upgraded, energy efficient windows and appliances.

- Prior to seeing the new solar panels, home buyers tended to prefer custom countertops over solar water heaters. Exposure to the new solar panels increased their interest in solar, particularly in relation to upgraded kitchen countertops.

- The most popular upgrades were ones that had the potential for direct cost savings for the consumer (energy-efficient windows and appliances and solar water heater). The upgrade options that were of least interest to these recent home buyers were home security systems and fireplace with blower kit. 


\section{Home Upgrade Options: Total Sample}

- After seeing and hearing about the new solar technology, consumer interest in solar increased while interest in upgraded kitchen countertops declined.

$\%$ Extremely/Somewhat Likely to Buy

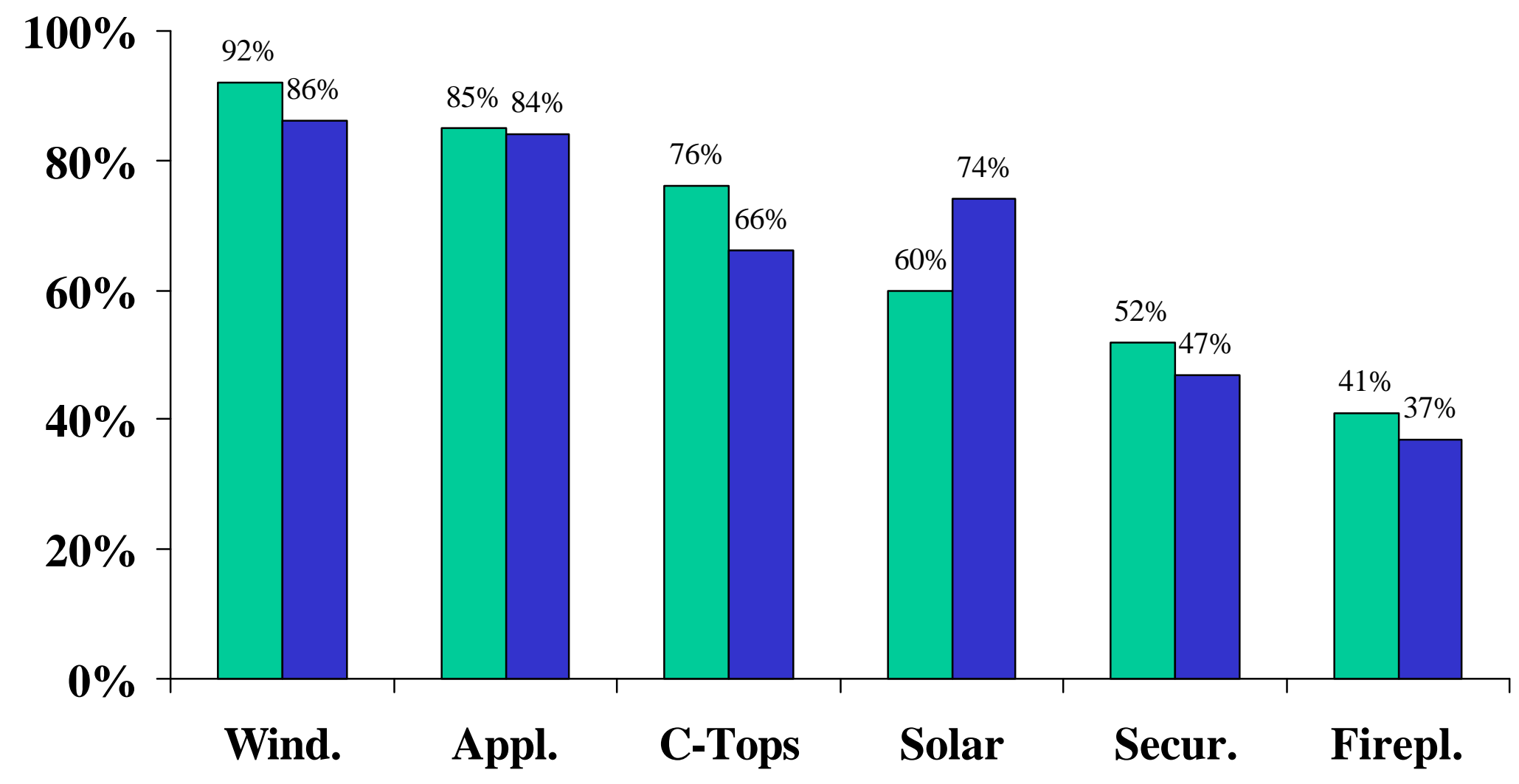

Before seeing new panels $\square$ After 


\section{Home Upgrade Options: Pairwise Trade-off}

- A second method for examining consumer preference for solar water heaters versus other home upgrade options utilized a pairwise tradeoff technique.

- Respondents asked to indicate their preference across each pair of home upgrade options by assigning "points" to each (total of 100 points per pair). The following new home upgrade options were assessed:

$>$ Home security system

$>$ Upgraded appliances

> Upgraded countertops

> Upgraded, energy efficient windows

$>$ Fireplace with blower kit

$>$ Solar water heater

- Participants were also asked to trade-off a $\$ 2,000$ savings off the sale price of the home. Thus, instead of choosing the upgrade option, they could elect to reduce the sales price by $\$ 2,000$. 


\section{Pairwise Trade-off Example}

- The following illustrates how the pairwise trade-off task was introduced to study participants. The example below shows 3 of the 21 pairs of options that were presented to study participants.

For each pair of upgrade options shown below, indicate which you would prefer by dividing 100 points across the two options. You can use any 2 numbers that add up to 100 . Remember the more you like an option, the more points you'd give that option.

Would you prefer ...

1. Upgraded windows pts. OR Upgraded appliances $\ldots$ pts. $=100$ pts.

2. Home security system pts. OR A $\$ 2,000$ discount pts. $=100$ pts.

3. Upgraded countertops pts. OR Solar water heater pts. $=100$ pts. 


\section{Home Buyer Preferences}

- Overall, home buyers were most likely to want the $\$ 2,000$ reduction in the sales price of the home. The average probability of selecting the $\$ 2,000$ discount was .23 , meaning that, on average, the $\$ 2,000$ discount was selected $23 \%$ of the time.

- Beyond the $\$ 2,000$ discount, preference for the upgrade options was rank-ordered in a way that was consistent with the post-measure purchase interest ratings. Hi-performance, energy efficient windows was rated highest among the six options (.18) -- followed by energyefficient appliances (.16) and solar water heaters (.15).

- The solar water heater in the pairwise trade-off was preferred over upgraded kitchen countertops, home security and fireplace with blower kit. 


\section{Home Upgrade Options: All Respondents}

Probability of Selection

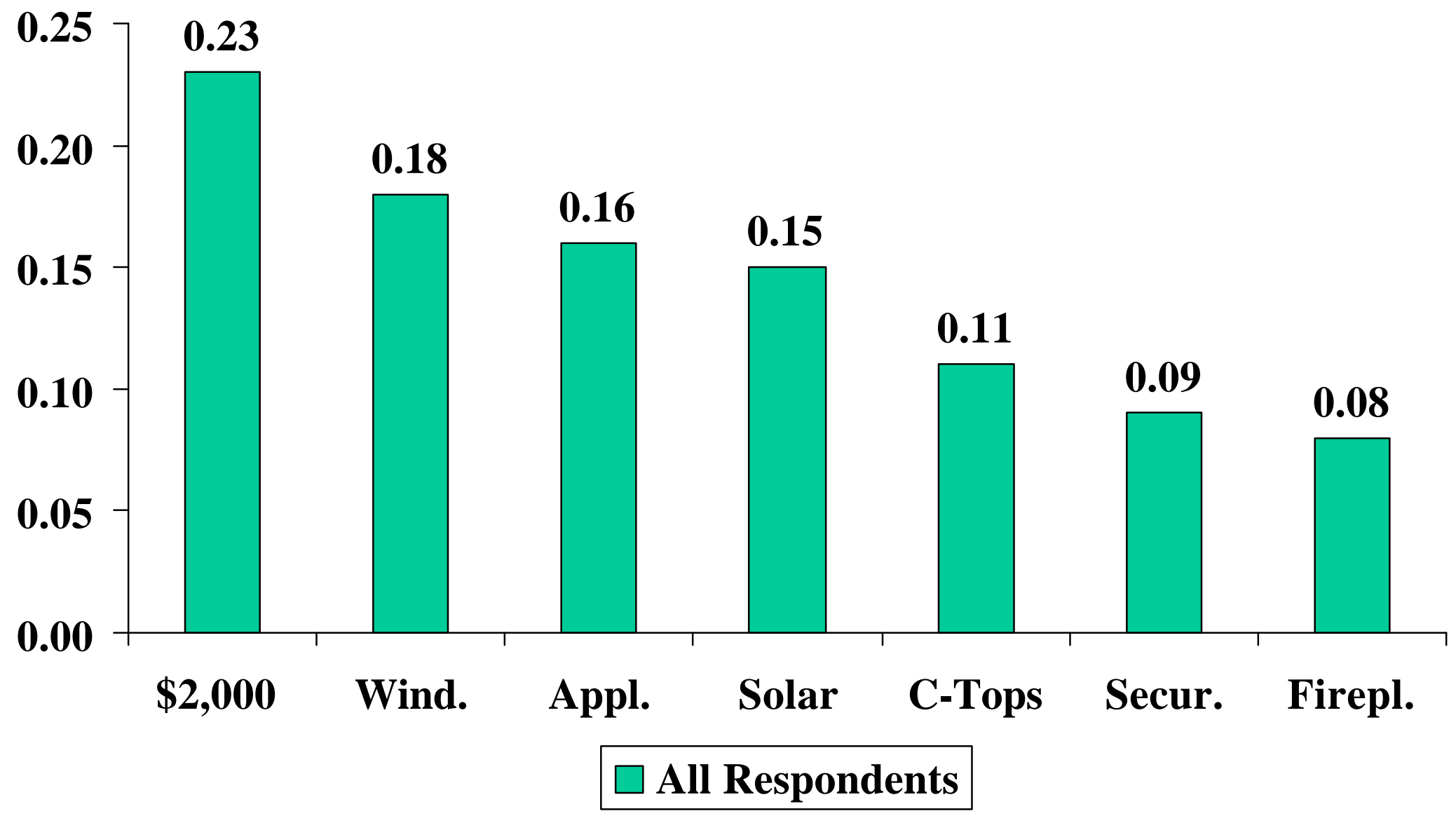




\section{Home Upgrade Options: Markets}

- Interest in solar was similar across markets. The Hi-End Phoenix market tended to be more interested in upgraded windows, while the Las Vegas market was particularly money-conscious.

Probability of Selection

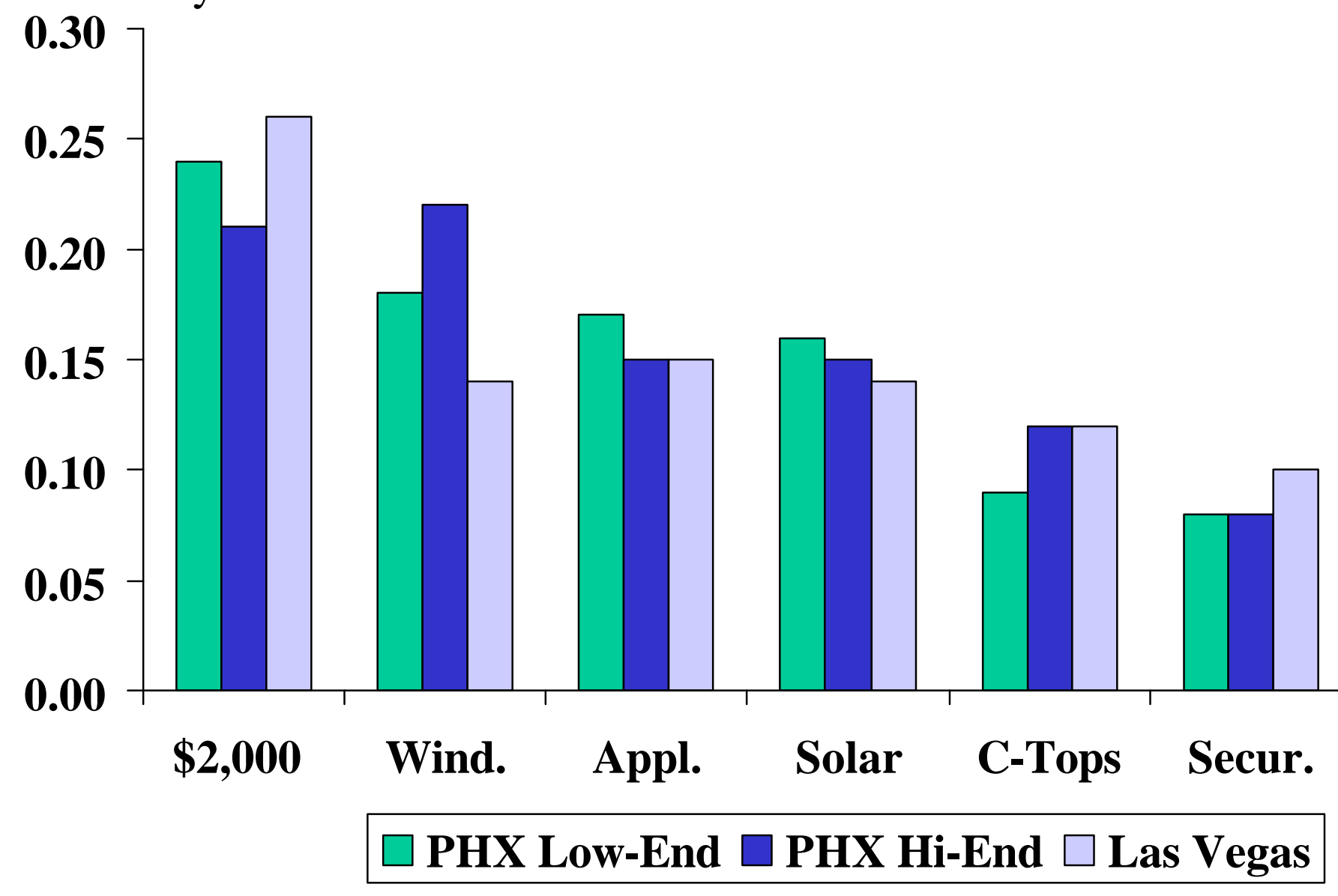




\section{Home Upgrade Options: SRP vs. APS}

- There were no significant differences between APS and SRP customers in terms of their interest in solar water heaters. APS customers were more likely to be interested in home security than SRP customers.

Probability of Selection

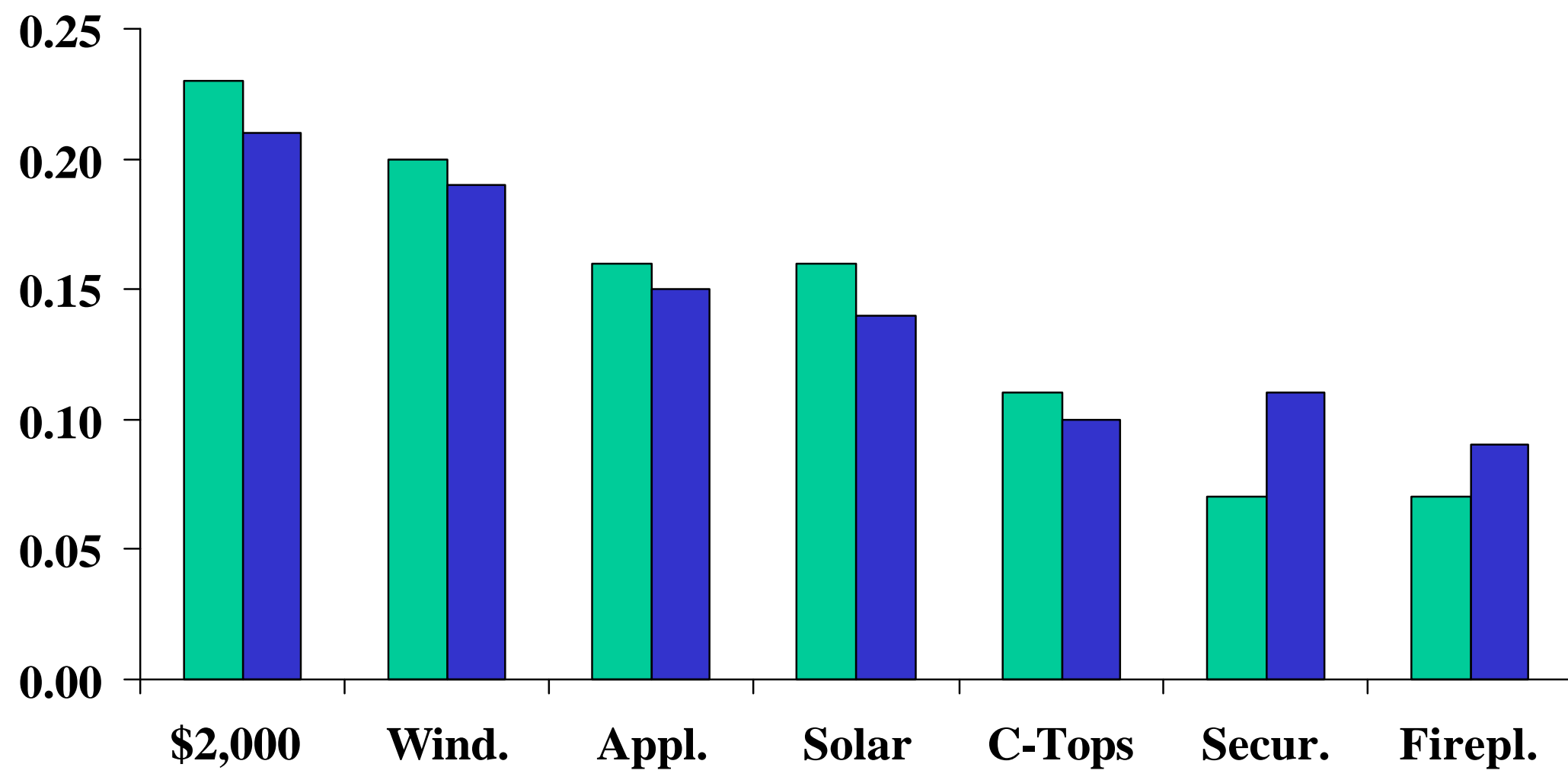

\section{$\square$ SRP Customers $\square$ APS Customers}




\section{Interest in Solar: Demographic Correlates}

- Several analyses were conducted to determine the extent to which certain demographic groups were more likely than others to prefer solar water heaters. Respondents more likely to be interested in solar included people ...

$>$ in larger homes

$>$ who have friends/relatives with solar water heaters

$>$ who are more environmentally-conscious

- Although current owners of solar water heaters were not included in the study, those who had a solar water heater in a previous home were more likely to be interested in the new solar technology than home owners with no previous solar water heater experience.

$>$ This finding suggests that home owners with previous experience with solar water heaters would be a good target market for the new technology. This appears to be consistent with focus group findings which indicated favorable opinions of solar among current owners of solar water heaters. 


\section{Home Upgrade Options: Friends with Solar}

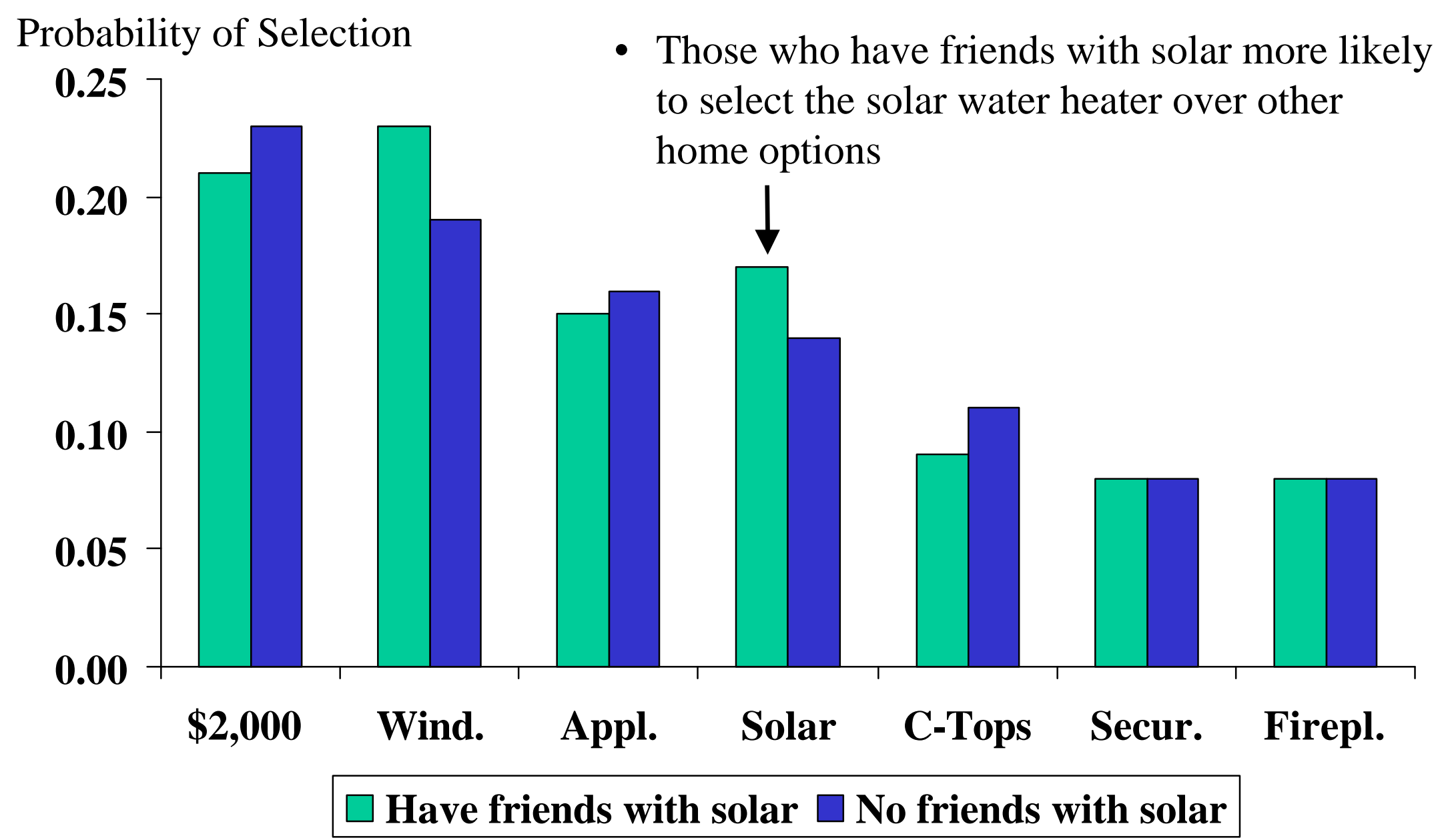




\section{Home Upgrade Options: Environment}

Probability of Selection

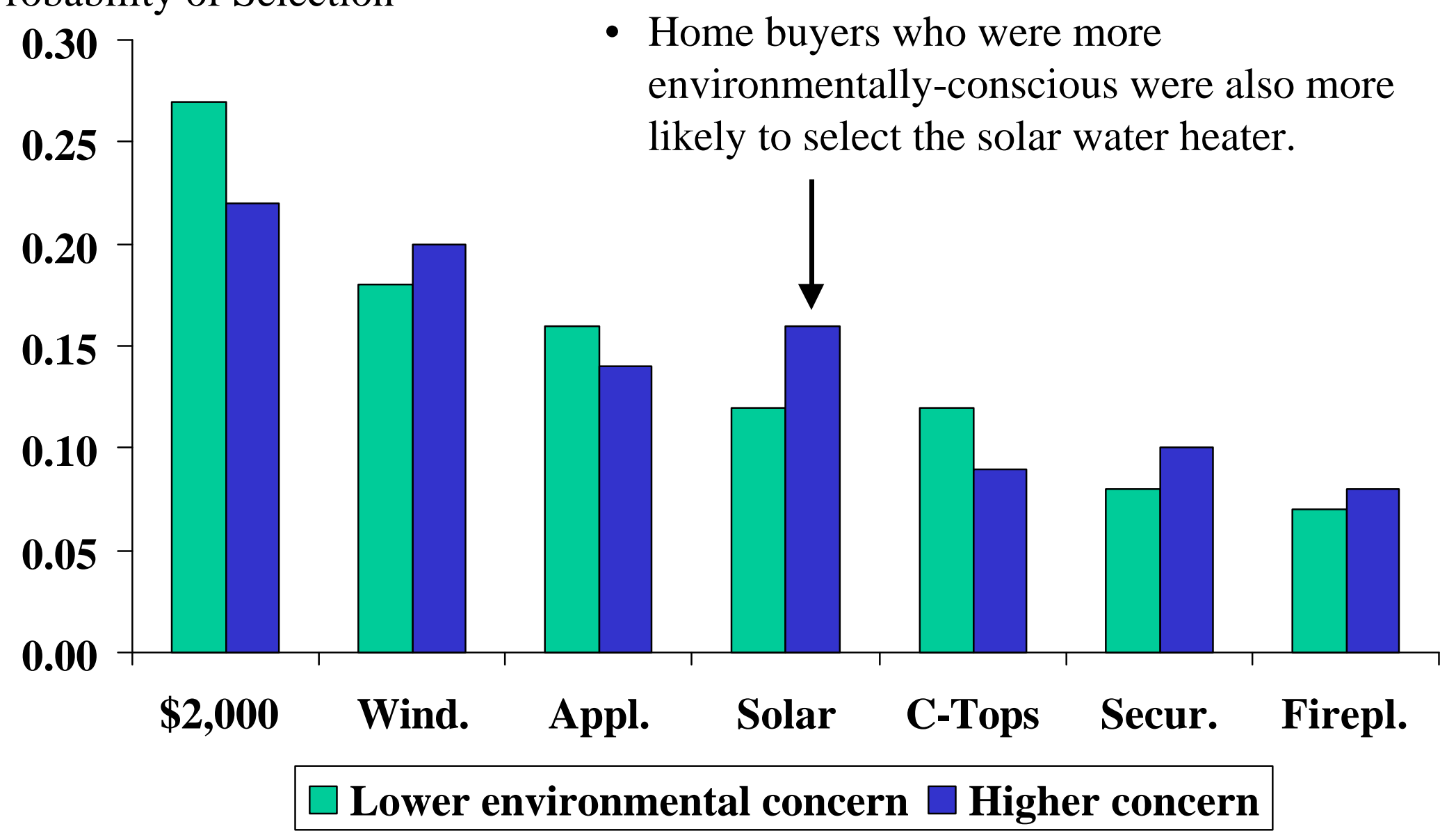




\section{Home Upgrade Options: Household Income}

Probability of Selection

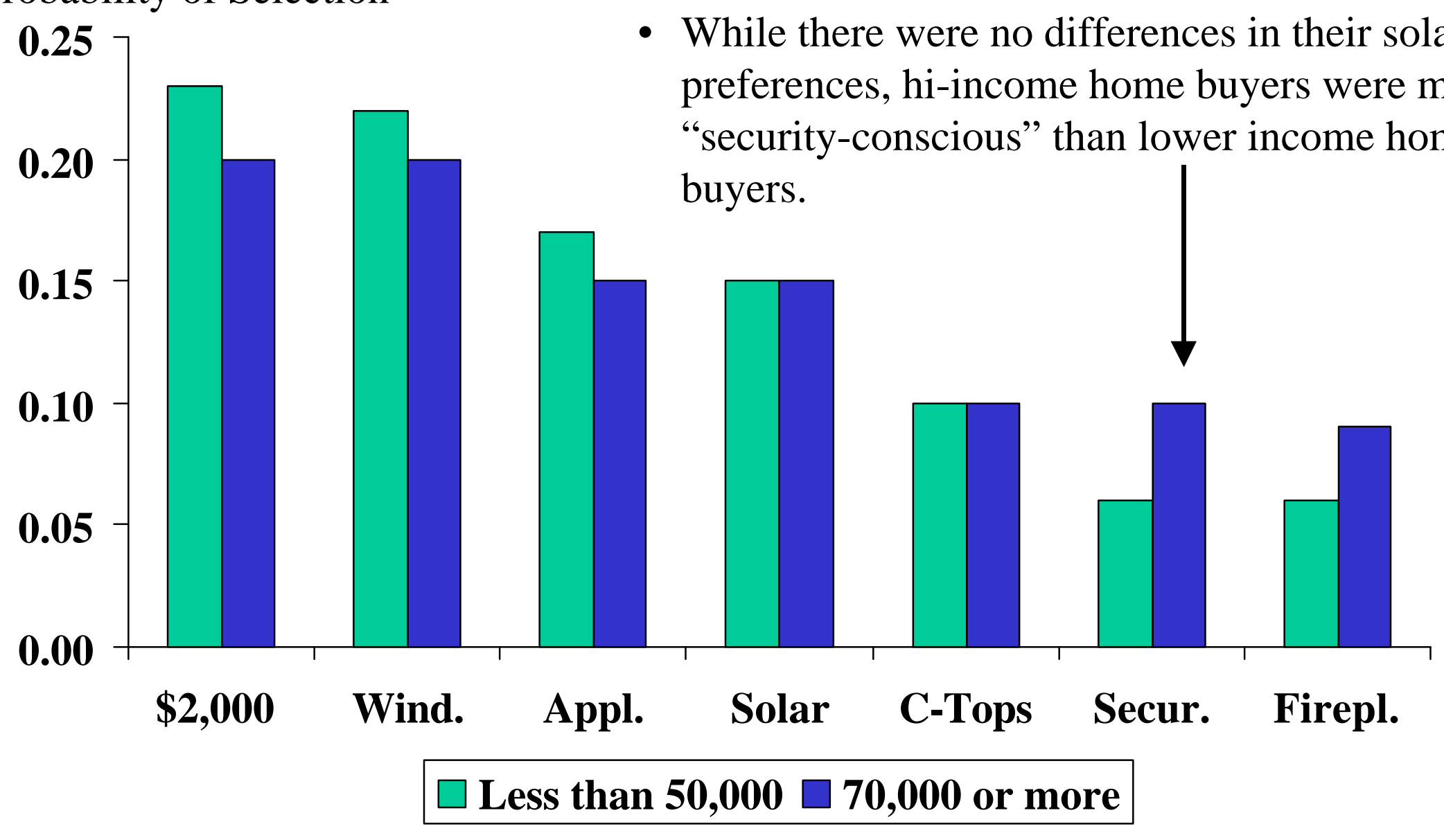




\section{Research Question \#2}

- What are the optimal solar water heater designs taking into consideration consumer preference and product feasibility?

$\checkmark$ Method

$>$ Conjoint Analysis using a fractionalized design

$>6$ product features, each with 3 levels of variation

> 729 possible combinations (profiles) represented by 27 randomly selected profiles

$>$ Respondents asked to sort and rank order 27 profiles according to their preference and likelihood of consideration 


\section{Product Features \& Attributes}

- Appearance

> Basic blue/gray color with glossy finish

$>$ Custom color, coordinated with your house and a glossy finish

$>$ Custom color, coordinated with your house and a textured nonreflecting finish

$\checkmark$ Capacity

$>$ Provides $40-50 \%$ of your hot water needs (one $4 \times 8$ panel)

$>$ Provides $70-80 \%$ of your hot water needs (two $4 \times 8$ panels)

$>$ Provides $90-100 \%$ of your hot water needs (three or more $4 \times 8$ panels)

- Brand -- Backed by...

$>$ Salt River Project

$>$ A well-known, national company

$>$ No known brand or company name 


\section{Product Features \& Attributes (Cont'd)}

- Warranty

> Standard 3 year warranty (no extra charge)

$>$ Extended 5 year warranty $(\$ 100$ - $\$ 150$ extra)

$>$ Premium 10 year warranty $(\$ 200$ - $\$ 300$ extra)

$\checkmark$ Location

$>$ Installed on the roof of your house

$>$ Installed on the wall of your house

$>$ Installed on the ground in your yard

$\checkmark$ Price

$>$ Installed price of $\$ 1,000$

$>$ Installed price of $\$ 2,000$

$>$ Installed price of $\$ 3,000$ 


\section{Conjoint Overview}

- For the conjoint task, DMUs were first given an overview of solar water heaters. This overview consisted of a written description of the newer solar technologies which was read to them aloud by the interviewer. Following this written and verbal description, they were shown two 8x10 color photos of solar panels installed on people's homes. (These photos were provided to Symmetrics Marketing Corp. by NREL.)

- Following this introduction to solar, DMUs were given a stack of 27 individual cards that contained written profiles of solar water heaters. Each profile presented a different mix of product features and attributes. Individuals or couples were asked to perform the tasks outlined on the next page. 


\section{Conjoint Tasks}

- DMUs (individuals or couples) completed the following tasks:

$>$ Review the 27 cards and sort them into one of three piles (Would Consider, Might or Might Not Consider, Would Not Consider).

$>$ For those in Would Consider and Would Not Consider piles, they further divided them into Definitely Would Consider, Probably Would Consider, Probably Would Not Consider or Definitely Would Not Consider.

$>$ Next, the DMU took the cards from each of the 5 piles (one pile at a time) and rank-ordered the cards from top to bottom (i.e., from the on they liked the best to the one they liked the least in that pile.) The end result was a rank-ordering of all 27 product profiles from 1 (like most) to 27 (like least).

> Finally, the interviewer pulled out top 5 cards for each DMU and asked the DMU to rate each of the top 5 cards on a five-point purchase intent scale -- definitely would buy, probably would buy, might or might not, probably would not or definitely would not. 


\section{Conjoint Profile Example}

- Shown below is an example of the conjoint profiles presented to study participants. The following profile was one of 27 profiles shown to participants on $4 \times 6$ cards.

Appearance: $\quad$ Custom color coordinated with your house and a glossy finish

Capacity: $\quad 40-50 \%$ of hot water needs (one $4 \times 8$ panel)

Backed by: A well-known, national company

Warranty: $\quad$ Extended 5-year (\$100-\$150 extra)

Location: Roof

Price: $\quad \$ 3,000$ 


\section{Comment on Payback/Cost Savings}

- In the design phase of this research the team wrestled with the idea of including monthly cost savings and projected payback period in the conjoint card sort task. Since cost savings and payback were a function of performance/capacity and installed price, we considered including projected cost savings and payback period as characteristics that would be estimated and included on each profile. (Technically, we would not "vary" savings and payback in the conjoint analysis since they would be derived from other features.)

- When we included savings and payback in the pretest, we found that many participants instantly focused on those numbers and ignored the other features entirely. Since savings and payback were not being directly varied in the conjoint analysis, we elected to omit them from the product profiles. Instead, we allowed participants to estimate cost savings and payback period for themselves if they were so inclined. In order to insure that participants understood the issues of cost savings and payback, we provided them with expected ranges during the general description of the new solar water heater systems. 


\section{Major Findings: Product Features}

- Three major drivers of consumer preference

$>$ System capacity --consumers are concerned about the percent of their hot water needs provided by solar

$>$ Location -- consumers have very clear expectations about the location of the system (roof, wall or ground)

$>$ Price -- as expected, consumer preference is very driven by price

$\checkmark$ Secondary driver

> Brand association -- it clearly does matter to home buyers whether the solar system is backed by a credible, trust-worthy company

- Not a major issue

$>$ Appearance (as defined) or Warranty terms -- as long as the system meets the basic appearance criteria described consumers are satisfied. Similarly, of the system is backed by a credible source, the warranty terms become less important. 


\section{Worst Case vs. Ideal System}

- Worst Case: Home buyers clearly not interested in a system that --

$>$ only provides $40-50 \%$ of their hot water needs

$>$ is located anywhere but on the roof

$>$ costs $\$ 3000$, and

$>$ is marketed by a company they've never heard of

- Ideal system would --

$>$ provide $90-100 \%$ of their hot water needs

$>$ be roof-mounted

$>$ cost $\approx \$ 1000$

$>$ be marketed by their local utility

- The value of conjoint analysis is the ability to determine the potential for success of product scenarios that fall somewhere between the ideal and the worst case. 


\section{Top Product Profiles}

- The ideal system as discussed earlier would be one with "all the bells and whistles" for the lowest possible price. Conjoint analysis allows the researcher to examine preferences for all possible product profiles, not just the sub-set that was presented to the study participants. When all 729 possible profiles are rank-ordered, the Top 14 profiles all have the following features:

$>$ Roof mount, $90-100 \%$ capacity, $\$ 1,000$

- These "ideal" products may not be possible to produce or feasible to bring to market. As such, we need to look below this top tier to determine which profiles are appealing to consumers and feasible to manufacture/market.

- The table shown on the following page provides some examples of design options that were appealing to consumers yet more feasible from a manufacturing/marketing perspective. 


\section{Product Design Options}

- The following design options were among the top-ranked in this study.

\begin{tabular}{|c|c|c|c|c|c|}
\hline Capacity & Location & Price & Brand & Appearance & Warranty \\
\hline$\overline{90-100 \%}$ & $\overline{\text { Roof }}$ & $\overline{\$ 2,000}$ & $\overline{\text { National }}$ & $\overline{\text { Custom, glossy finish }}$ & 10yr Warranty \\
\hline $90-100 \%$ & Roof & $\$ 1,000$ & SRP & Basic gray, glossy & 5yr Warranty \\
\hline $70-80 \%$ & Roof & 00 & SRP & on-reflecting & Varranty \\
\hline $70-$ & Roof & 000 & National & ssy finish & Varranty \\
\hline $90-100 \%$ & Roof & $\$ 2,000$ & SRP & Custom, non-reflecting & 10yr Warranty \\
\hline
\end{tabular}




\section{Conclusions}

- While solar water heaters suffer from a bad reputation, the new solar technology has potential with new home buyers.

- Interest in solar water heaters increased substantially once home buyers were "educated" about the new technology.

- The major perceived advantage to solar is lower energy costs -- solar marketers need to be able to demonstrate cost advantage and payback to home buyers.

- Home buyers currently have clear perceptions of the disadvantages of solar water heaters. Solar marketers need to eliminate perceived disadvantages -- high initial cost, unattractive, unreliable, vulnerable to bad weather 


\section{Conclusions (cont'd)}

- In this study, solar water heaters were not as popular as upgraded energy-efficient windows or appliances but were more popular than upgraded countertops, home security or fireplace.

$>$ The top-3 (windows, appliances and solar) all have the potential to save money for the home buyer over time

$>$ Other features (upgraded countertops, home security, fireplace) may be viewed as less practical

- On average, home buyers would rather have a reduction in the price of their home ( $\$ 2,000$ as tested in this study). Upgrade options may be viewed as luxury, not essential. 


\section{Conclusions (cont'd)}

- The study was not able to identify any strong relationships between demographics and interest in solar water heaters. People were more likely to be interested in solar, however, if they had some prior experience with solar -- either in a previous home or through friends and neighbors. The following home buyer types were most likely to be interested in solar water heaters:

$>$ People in larger homes

$>$ People who have friends/relatives with solar

$>$ People who have previously owned a solar water heater

$>$ People who are more environmentally-conscious 


\section{Conclusions (cont'd)}

- The biggest perceived disadvantage to solar is high initial cost. Home buyers will not consider solar water heaters if priced over $\$ 2,000$. Most expect the product to be in the $\$ 1,000$ to $\$ 1,500$ range.

- The three major drivers of consumer preference--

$>$ System capacity: more is better (at least 70-80\% of needs)

$>$ Location: prefer it on the roof

$>$ Price: $\$ 1,000-\$ 1,500$ range

- Consumers also want the confidence of a local utility or nationallyknown firm backing the product.

- Not as concerned with Color options or Warranty 


\section{Conclusions (cont'd)}

- Interest in solar water heaters was largely driven by price and performance

$>$ Consumers do not want to rely heavily on a backup water heater; they want nearly all of their hot water needs provided by solar -- if this is not feasible, consumer education will be required to convince them of its value.

$>$ Consumers do not want to spend $\$ 2,000-\$ 3,000$ for a water heater -- for that kind of money, the payback is way too long

- Solar marketers need to determine what type of unit can satisfy this price/performance trade-off 


\section{Final Comment}

- The success of solar water heaters is dependent upon multiple players: manufacturers, builders, realtors, consumers. Consumer interest alone will not guarantee success.

- Solar marketers need to demonstrate to builders that there IS consumer interest in the product. This study strongly supports this view.

- Consumers will adopt solar if --

$>$ the cost/benefit is favorable to them

$>$ builders/realtors push the product 


\section{Demographics}

- Demographic Note:

> The sample of home buyers recruited in Las Vegas tended to be older and of a lower socio-economic status than the sample recruited in Phoenix. This may have been due to several factors -demographics of recent home buyers in Las Vegas, demographics near the focus group facilities, differences in recruitment lists. In spite of these differences, we did not see any major differences in solar preferences according to demographic variations.

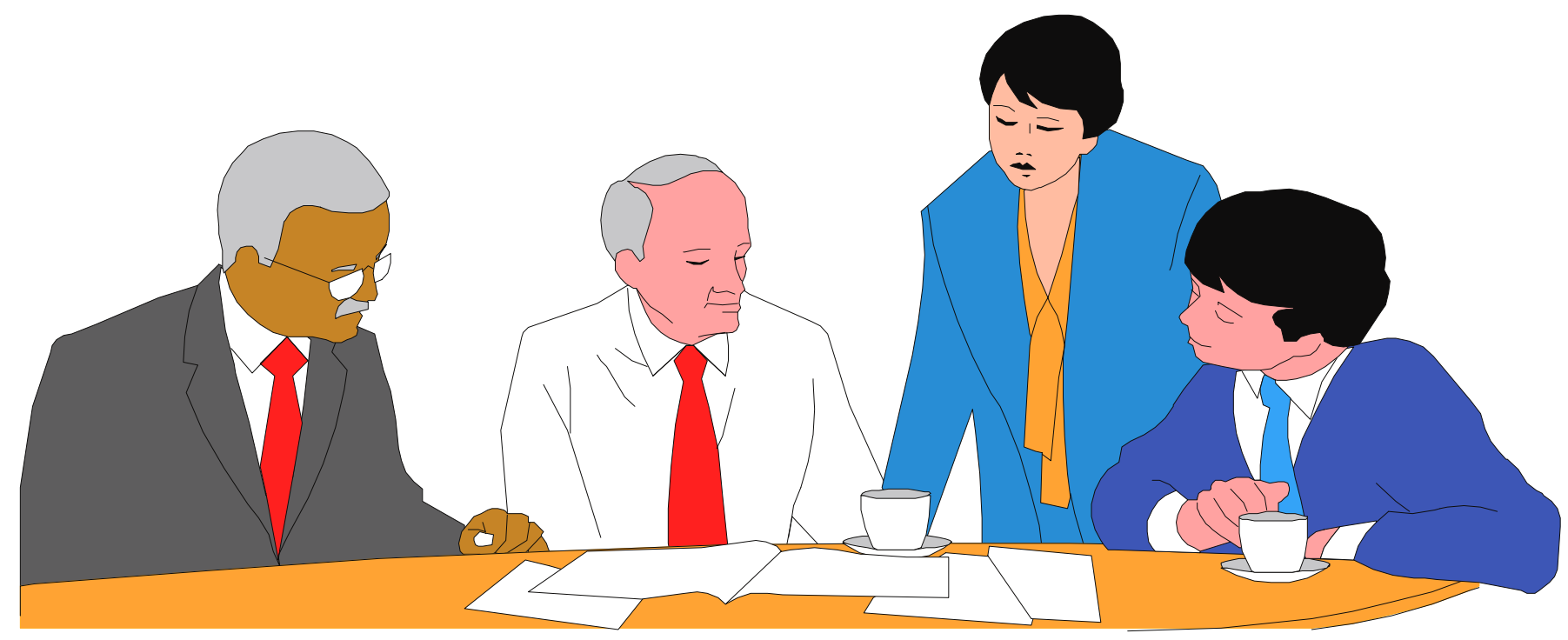




\section{Household Composition}

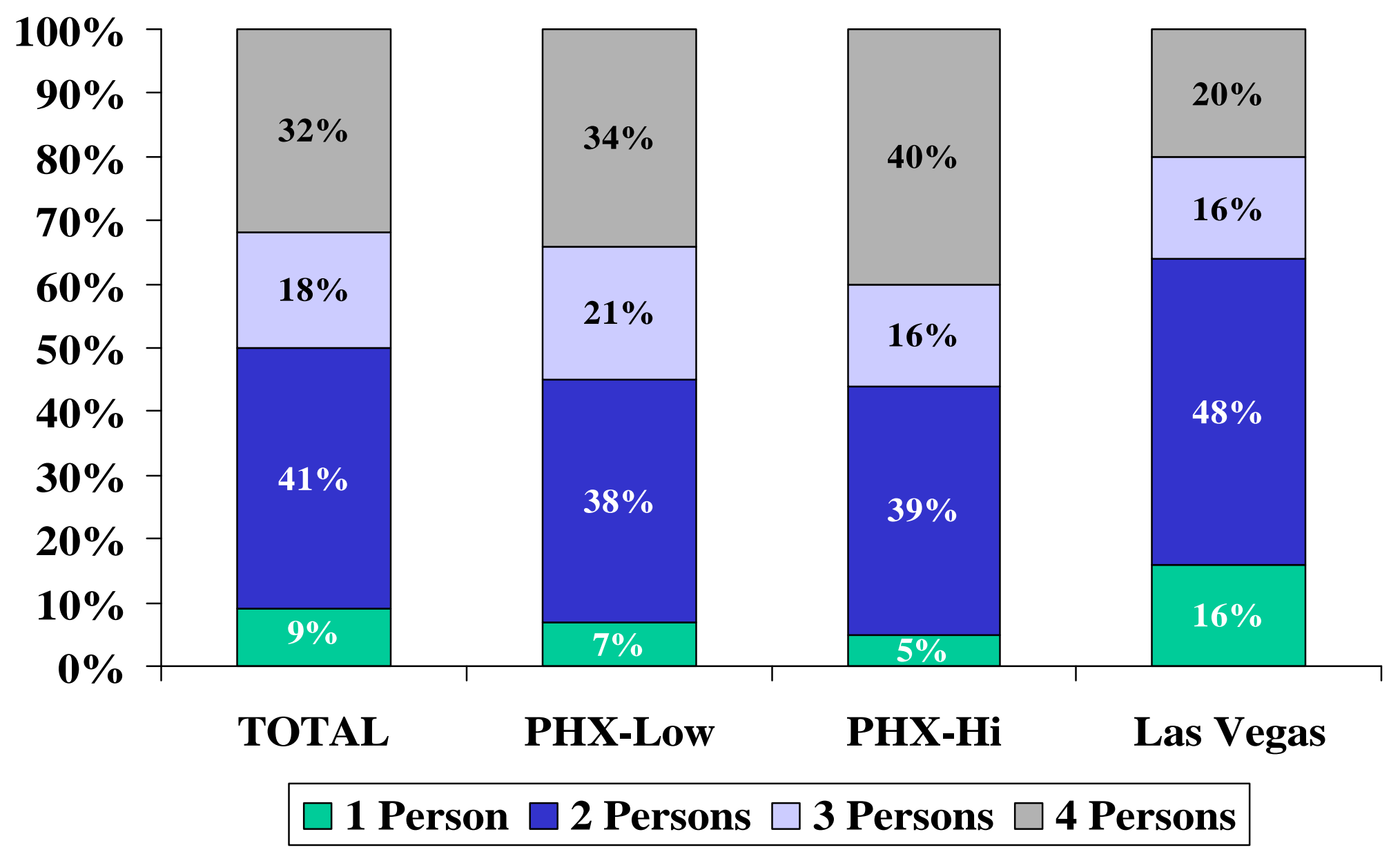




\section{Home Size}

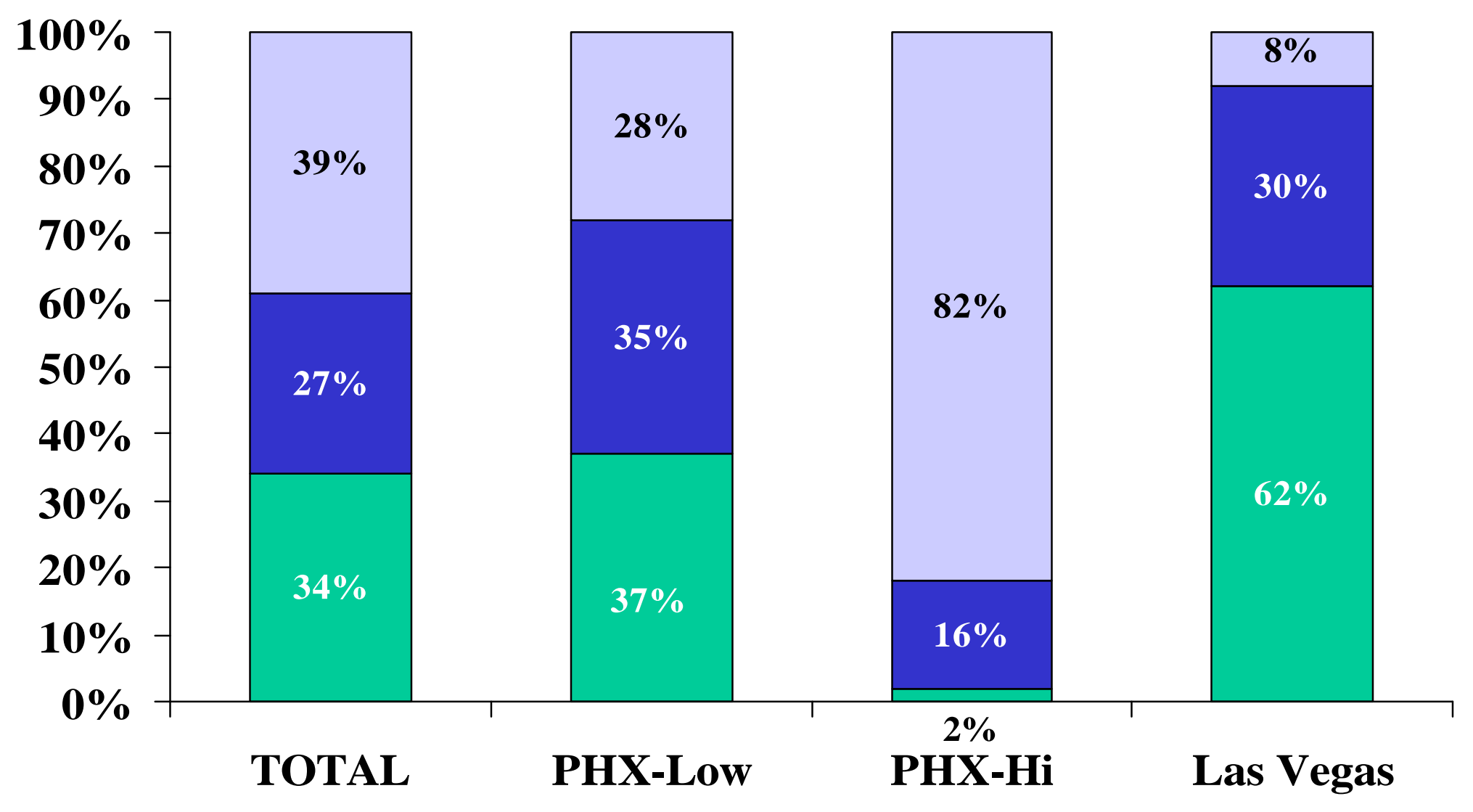

$\square$ Up to 1650sq ft $\square$ 1651-2000 sq ft $\square$ Over 2000 sq ft 


\section{Age}

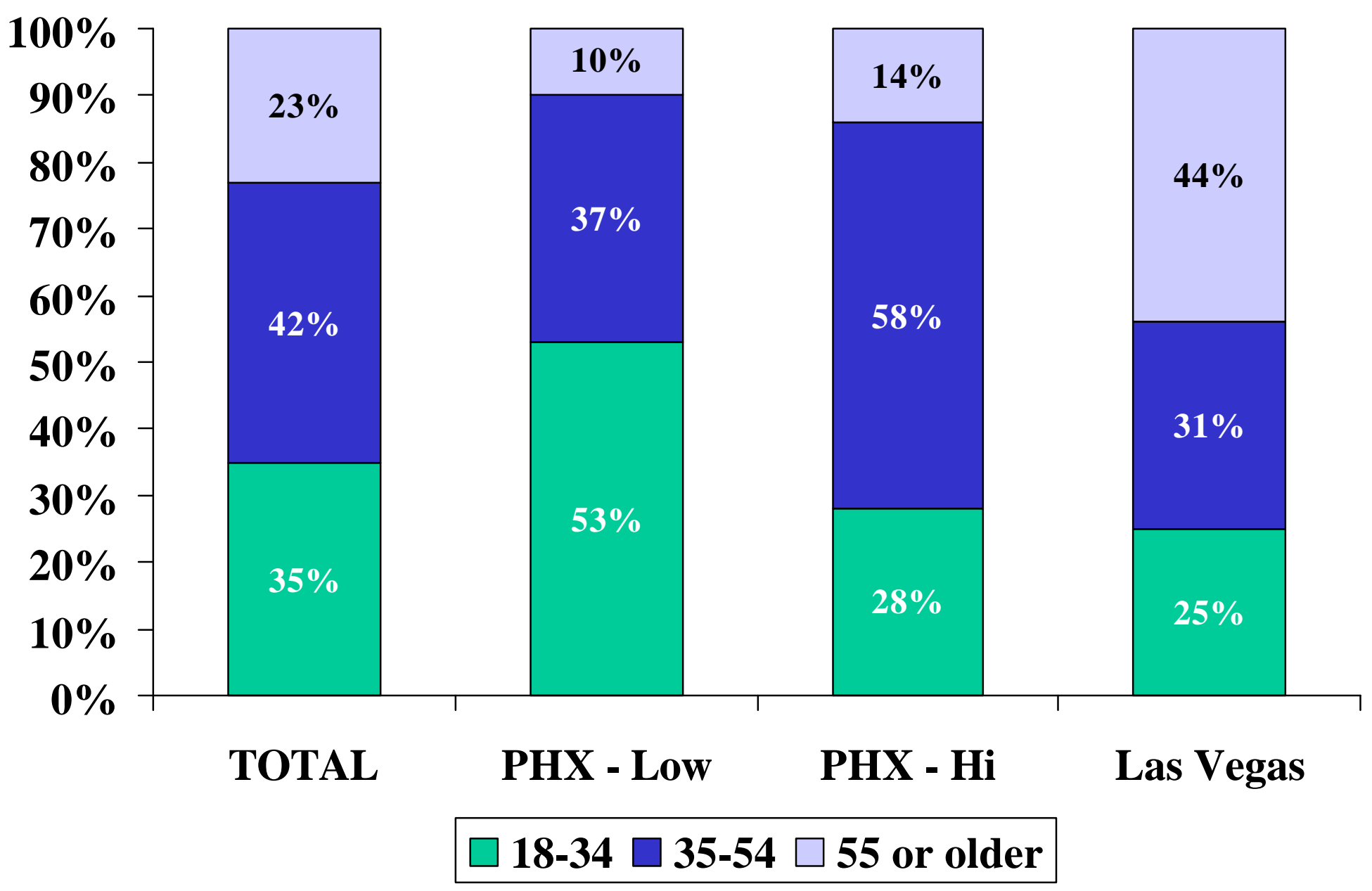




\section{Income}

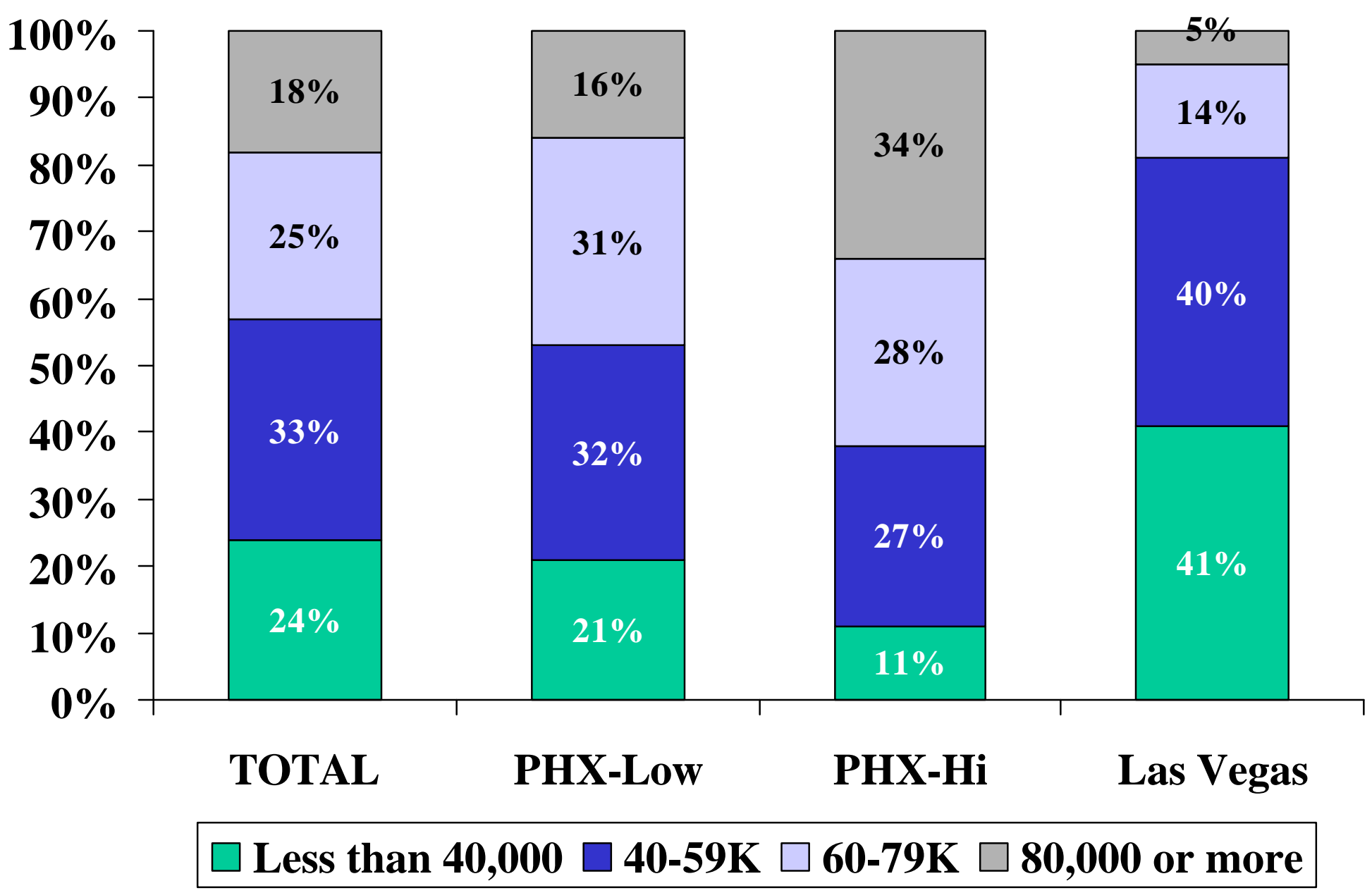




\section{College Graduates}

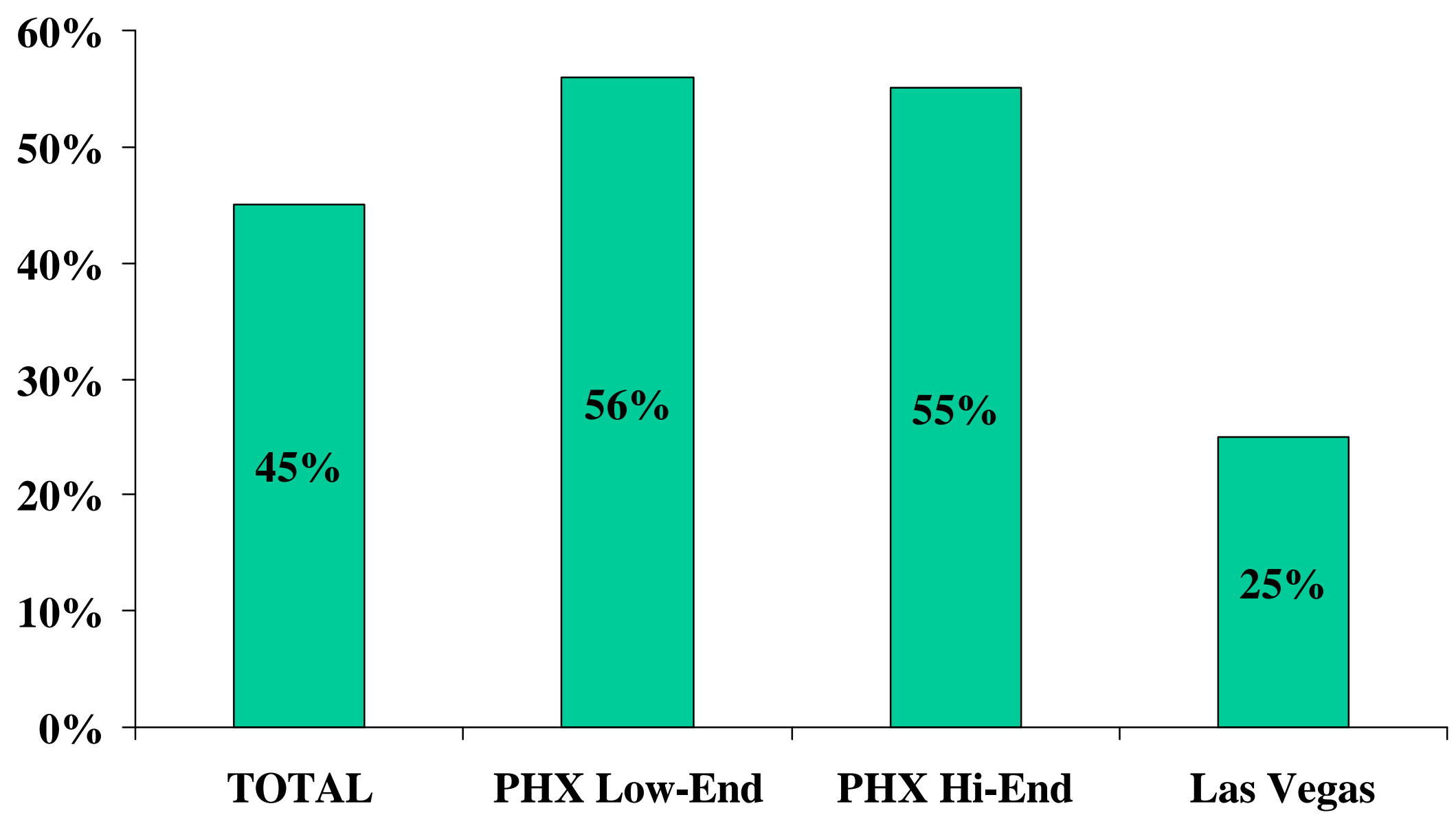




\section{Power Provider}

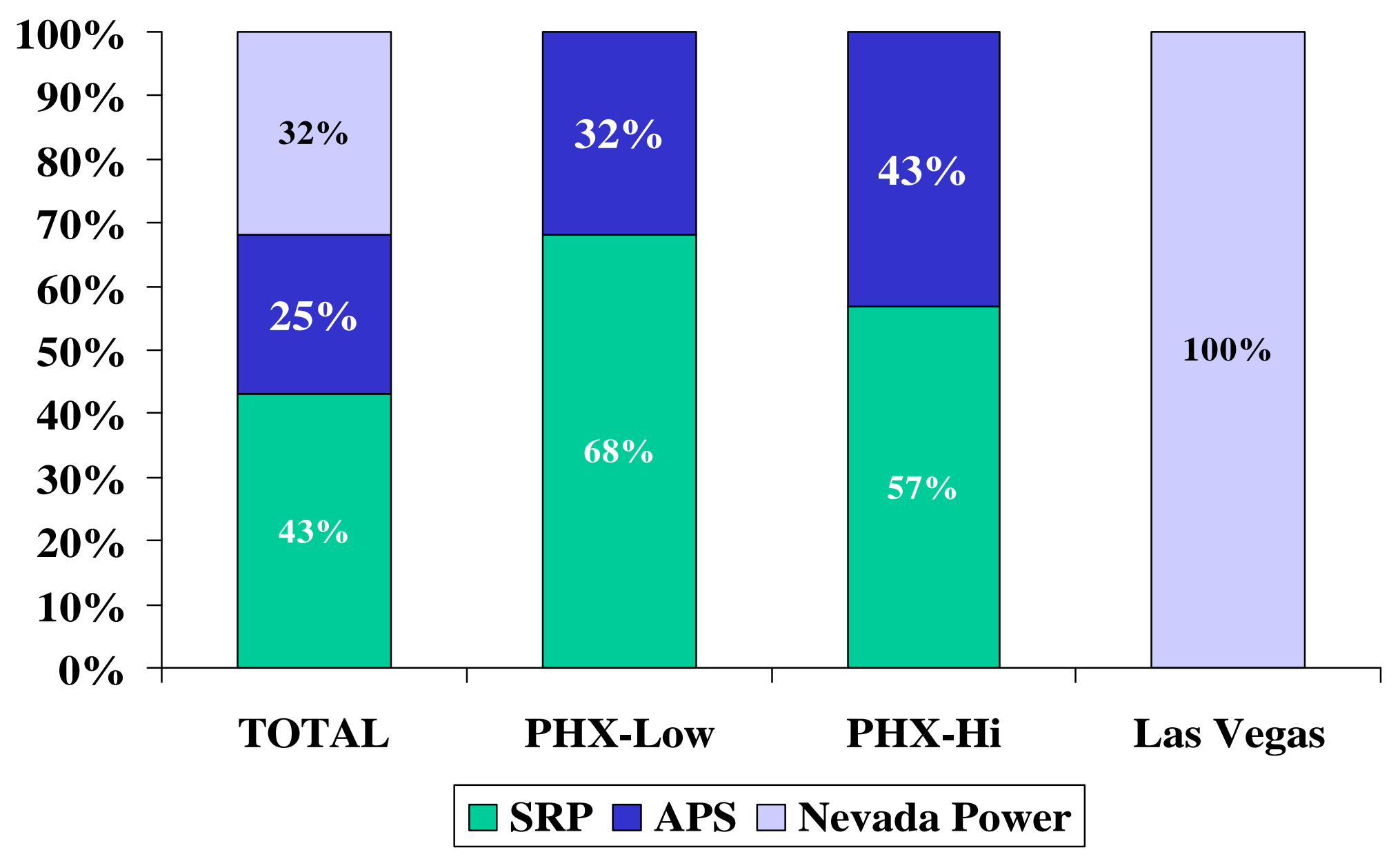




\section{Solar Payment Preferences}

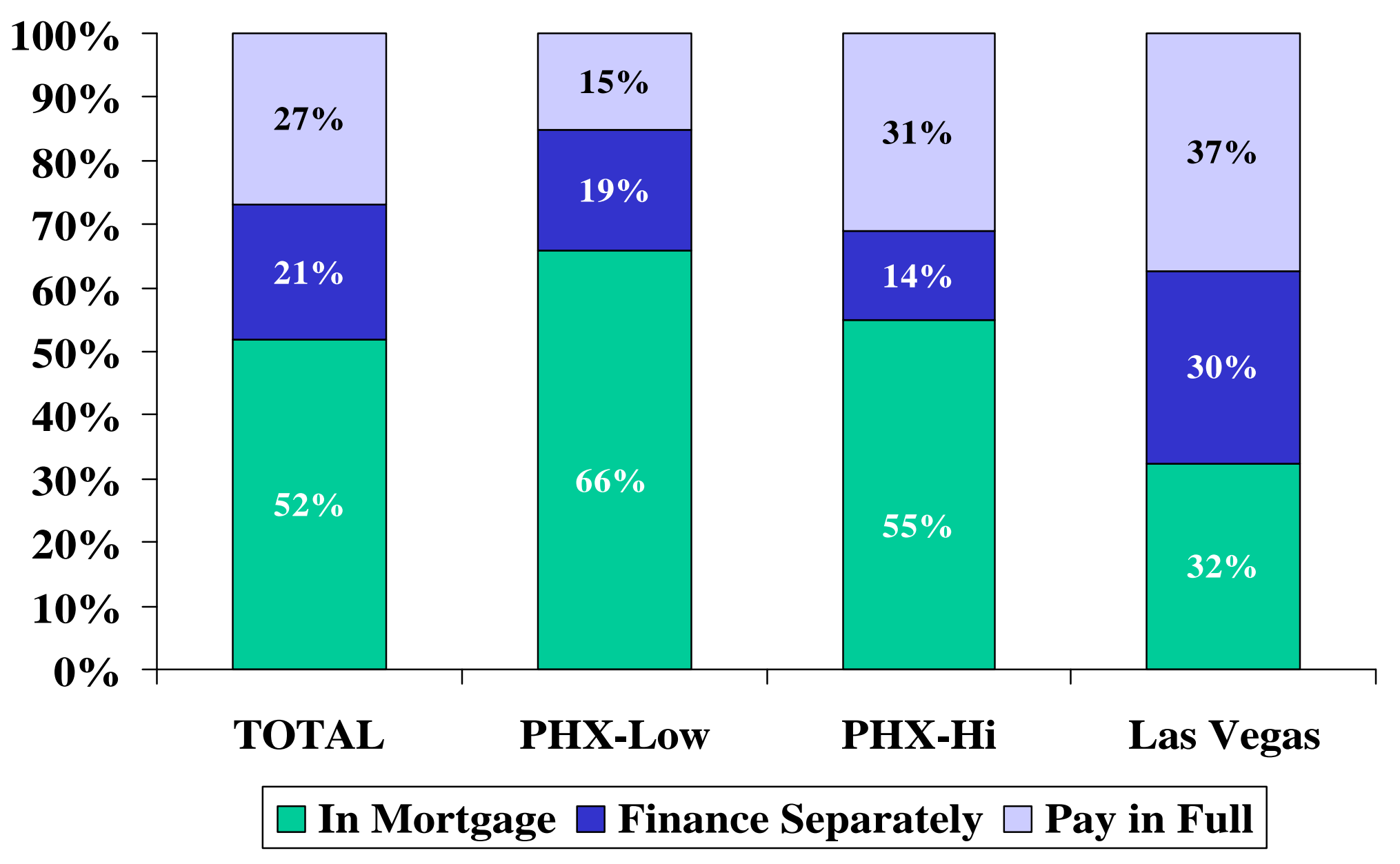




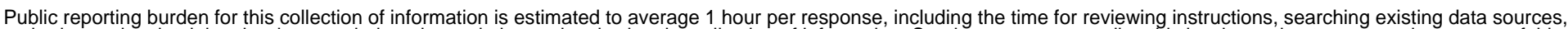

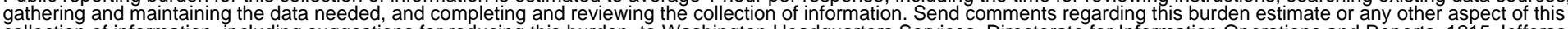

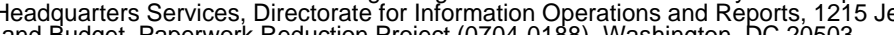

Davis Highway, Suite 1204, Arlington, VA 22202-4302, and to the Office of Management and Budget, Paperwork Reduction Project (0704-0188), Washington, DC 20503.
1. AGENCY USE ONLY (Leave blank)
2. REPORT DATE
June 1998
3. REPORT TYPE AND DATES COVERED
Subcontract Report

4. TITLE AND SUBTITLE

New Home Buyer Solar Water Heater Trade-Off Study

SH71 5004

6. $\operatorname{AUTHOR}(\mathrm{S})$

Symmetrics Marketing Corporation

7. PERFORMING ORGANIZATION NAME(S) AND ADDRESS(ES)

Symmetrics Marketing Corporation

1201 South Alma School Road, Ste. 2550

Mesa, AZ 85210

8. PERFORMING ORGANIZATION REPORT NUMBER

Salt River Project

PO Box 52025

Phoenix, AZ 85072

National Renewable Energy Laboratory

1617 Cole Boulevard

Golden, Colorado 80401-3393

SR-550-26846

9. SPONSORING/MONITORING AGENCY NAME(S) AND ADDRESS(ES)

10. SPONSORING/MONITORING AGENCY REPORT NUMBER

U.S. Department of Energy

1000 Independence Ave., SW

SR-550-26846

Washington, DC 20585

11. SUPPLEMENTARY NOTES

12a. DISTRIBUTION/AVAILABILITY STATEMENT

12b. DISTRIBUTION CODE

National Technical Information Service

U.S. Department of Commerce

5285 Port Royal Road

Springfield, VA 22161

13. ABSTRACT (Maximum 200 words)

This report details the results of a research conducted in 1998 and 1999 and outlines a marketing deployment plan designed for businesses interested in marketing solar water heaters in the new home industry.

14. SUBJECT TERMS

water heating, solar water heating, marketing, business plan, solar energy

15. NUMBER OF PAGES

52

16. PRICE CODE

17. SECURITY CLASSIFICATION OF REPORT unclassified

18. SECURITY CLASSIFICATION OF THIS PAGE unclassified
19. SECURITY CLASSIFICATION OF ABSTRACT unclassified
20. LIMITATION OF ABSTRACT

UL

NSN 7540-01-280-5500

Standard Form 298 (Rev. 2-89) Prescribed by ANSI Std. Z39-18 